\title{
抄錄
}

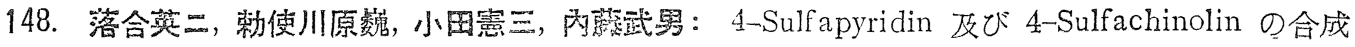
[芳查環状異項珤の分極 结 48 報 $]^{13}$

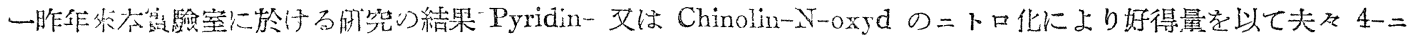

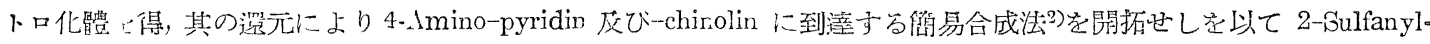

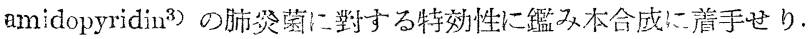

(A) 4-Sulfanylamidopyridin: 4-Aminopyr'din $10.5 \mathrm{~g}$ を p-Acetylaminobenzolsulfochlorid と無水アセトン中

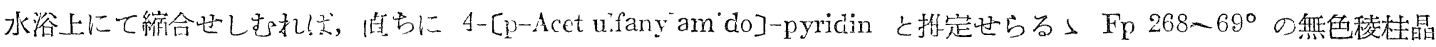

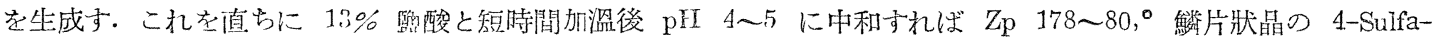

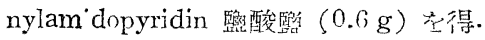

(B) 4-Sulfanylamido-chinolin: 4-Aminochinolin をp-Acetylaminobenzolsulfochlorid とアセトン溶液中重曹 の存在下に縮合せしむ扎ば 4-[1-A etsulfany'am:do]-chinolin と推定せらる〉結晶を生成するも，本物質は極みて加

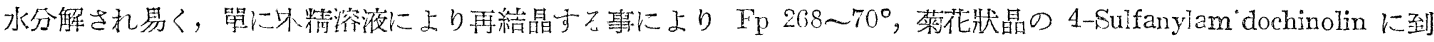
澾せり。此の場合脫アセテル化を酸又はアルカリで行へば,直ちにAminochinolin に分解す。偷ほ未精再結晶に際し，

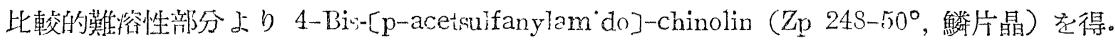

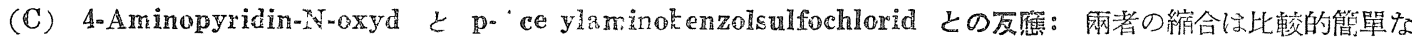

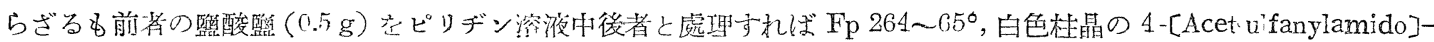

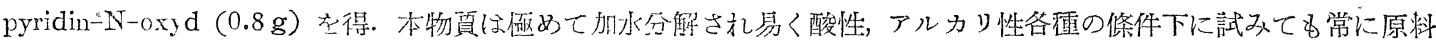

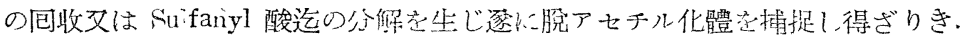

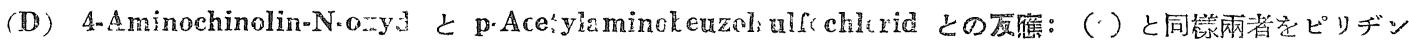

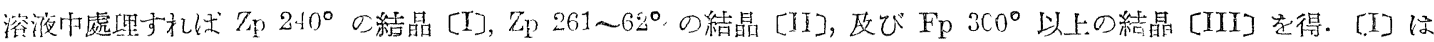

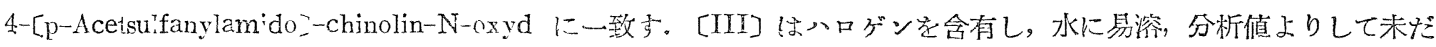

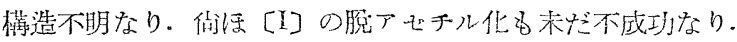

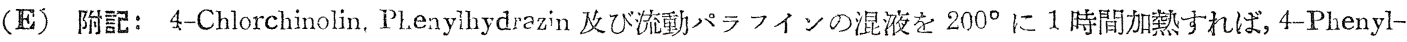

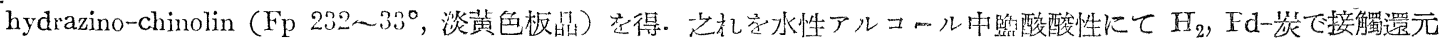

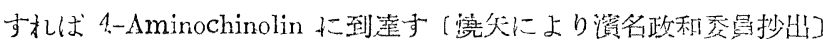

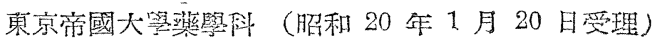

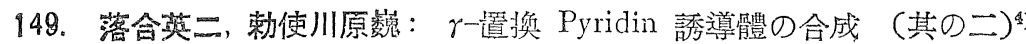

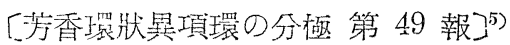

\section{(1) 4-Aminopyridin-N-oxyd[四]のアミ/基の愿應}

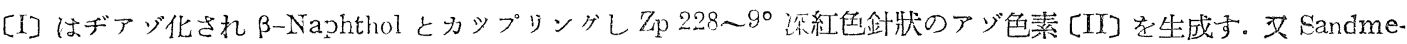

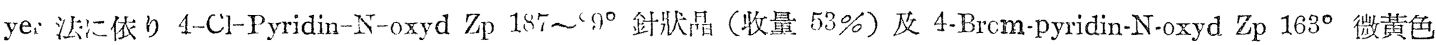

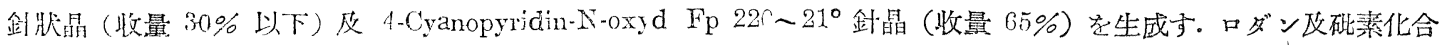
體に置換せ儿とせし子成功せず。

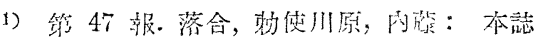

2) 本誌: $63,1.86 ; 64,201 \%$

3) Witby: I ancet, 235. I, 1210 (1939), ; Fleming; Lancet, 2 5, II, r4, 584, (1938)。

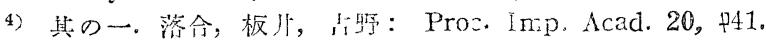

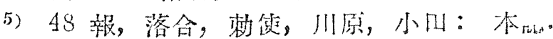



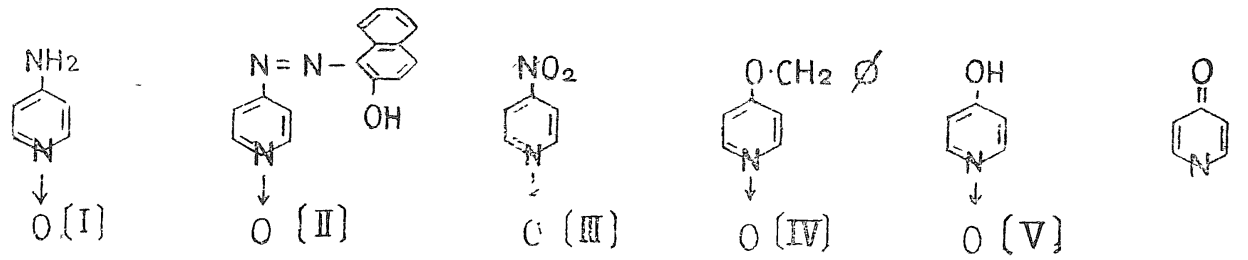

(2) 4-Eenzyloxypyridin-N•oxyd [IV 及びその分解

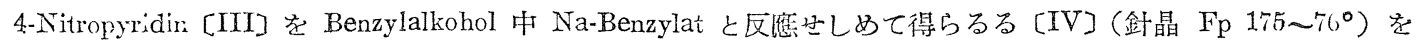

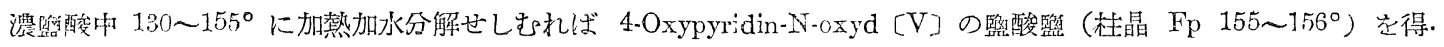

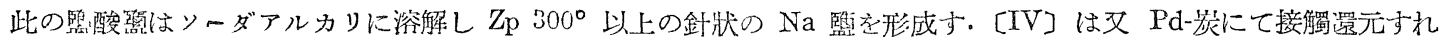

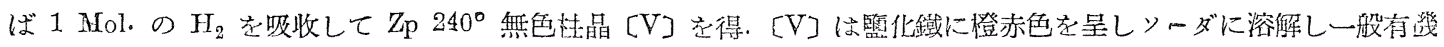

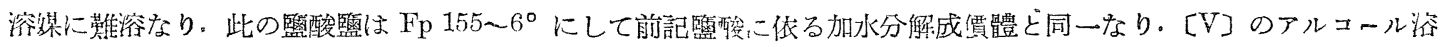<smiles>COc1ccc(O[Al]2CCCC2C2CCCC2)cc1</smiles><smiles>COn1ccc(=O)cc1</smiles>

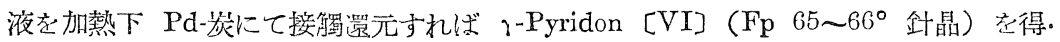
[V]をデアゾメタンにてメチル化すればベンッオールに可溶の Fp 75〜80 針晶

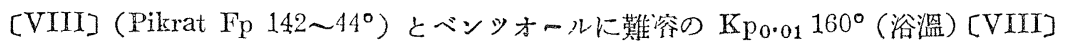
(Pikrat Fp 200 010) の独炎得.

4-Oxypyridin·N-oxyd [V] がヂアゾ×タンにて二種のメテル化體老與ふるに對し 1-Amino-pyridin-N-oxyd [I] はヂアゾメタンと区應せざる1)は興慗古る事實なり。

(3) 4.Arylpyridin-N-oxyd の合馬毁鸦
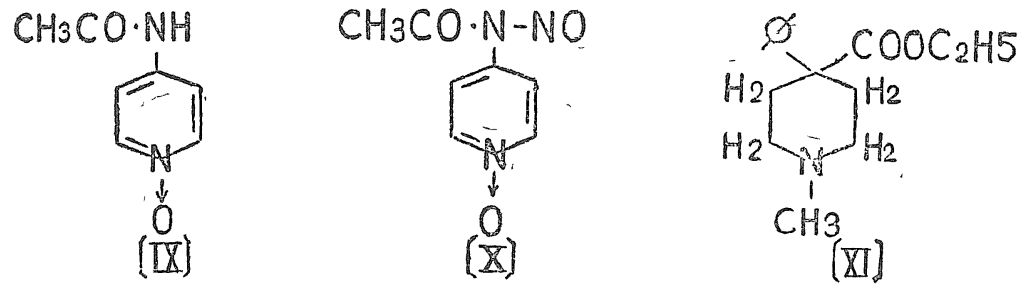

Howorth, Hey2) は Nitroøoacetanilid と Benzol より Diphenyl 含成せり・若し〔X〕を得らるれば之より

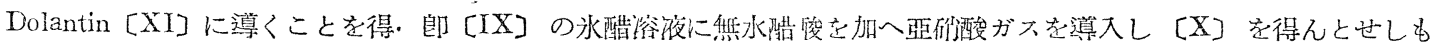

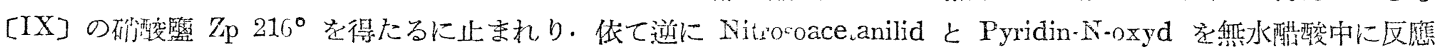
せしめたるに 4-Phenylpyridin-N oryd を得ずして Fp $135^{\circ}$ 该造不明の結晶走得たるのみなり。

(4) 4-Aminopyridin-N-oxyd [I] Q Eenzoyl 化

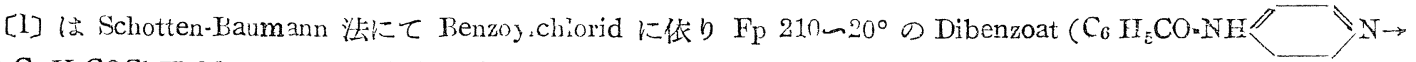
O. $\mathrm{C}_{6} \mathrm{II}_{5} \mathrm{COCl}_{2} \mathrm{H}_{2} \mathrm{O}$ ) 在定量的に生成し 4-Benzoylamno-2-oxypyr'din の副生を見ず。

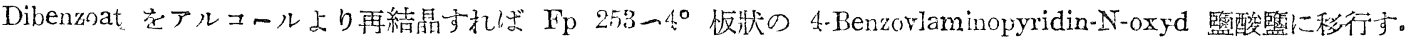

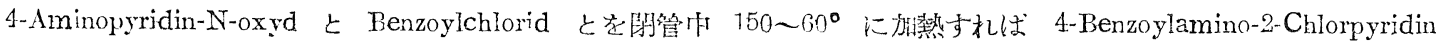

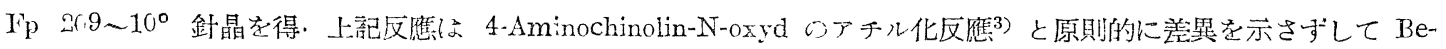

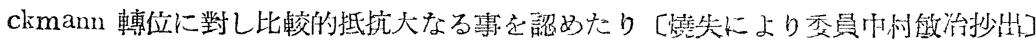

東大藥化學敎室（昭和-20 年 1 月 20 日）

\footnotetext{
I) 洛合, 附藤, 粲因: 本誌 64,211 。

2) Howorth, ITey: Soc. 1940, 361 .

3) 小田：本誌 (吅) 64,18 。
} 